\title{
The Peer of Decorative Hardwoods
}

\author{
Rosewood: What It Is, Where It Comes From, and What It Is Good For
}

By C. D. Mell

THE undisputed precedence among 1 fancy furniture woods has been coninto the world's markets. Manufacturers of the fine styles of furniture and interior trim consider it the epitome of beauty and elegance and the emblem of refined taste. It has been a favorite wood among makers of musical instruments and fancy cabinet work for about 300 years, as may be attested by the amount of antique rosewood furniture that has been handed down from generation to generation.

The word rosewood, as used in this article, has reference only to the genuine kind which emanates from Brazil under the local or Portuguese name of jacaranda cabiuna, or simply cabiuna. This word was introduced into the European markets prior to 1660 , and it is believed that consignments had reached France and England during the 16th century. There are evidences that rosewood furniture existed in the mansions of the nobility and gentry during the reign of Queen Elizabeth, for at this time the homes of the rich had acquired a splendor of fitting and finishing which they had not before displayed, and of which abundant evidence is even yet to be seen in some of the well-preserved old manor houses in England and among the exquisite decorative features in the castles of continental Europe.

Before the year 1600 full cargoes of dye woods were shipped out of Recife (Pernambuco) to Europe, and at a somewhat later date similar shipments emanated from San Salvador (Bahia), and among these were logs of rosewood which received the name of palisandre (a word corrupted from palo santo, meaning holy wood) in France, and rosenholz in Germany, because the odor of the wood resembles that of roses.

The earliest records refer to this wood as Pernambuco, which is the name of the province where the logs originated: later shipments emanated from the State of Bahia, and for many years it was known in England as Bahia wood, and a still later name was Victoria wood, so called because the logs were shipped from Victoria, a seaport town in the State of Espirito Santo. The two chief trade names which persist to the present time are palisandre and rosewood; the local binomial, jacaranda cabiuna, is rarely used in the trade. The scientific name is Dalbergia nigra.

The present supply of rosewood logs comes chiefly from regions south of Bahia, Victoria being the chief shipping port for this commodity, and approximately a thousand tons of it in the form of rough logs with the bark and sapwood hewn off are shipped into the United States annually. An equal quantity finds its way into the European markets. This quantity represents less than one-third of the stocks that were exported from Brazil during the days when rosewood was used more extensively than it is now.

The use of true rosewood in the United States has been on the decline for over two decades, and one of the chief reasons for this is that substitutes are now being introduced. Another reason for this is that large percentage of the $\operatorname{logs}$ show serious heart defects and that only a small proportion of the logs produce clear lumber, which is so essential in the manufacture of interior trim and cabinet work. As a result of the increasing number of poor quality logs in the shipments received here, consignments have frequently been rejected by consignees, and on account of the eventual sale of the logs at great sacrifice, the shippers at sources of origin refused to forward further stocks except upon the receipt of firm orders with letters of receipt of firm orders with letters of Dealers and commission houses here have always been reluctant to comply with such terms, and the result was that shipments of substitutes from other parts of the tropics were encouraged. Cocobolo and other so-called rosewoods have taken the place of true rosewood and are now in general use here. Upward of 2000 tons of these substitutes are being consteme? in the United States annually. The annual consumption of rosewood of all kinds in

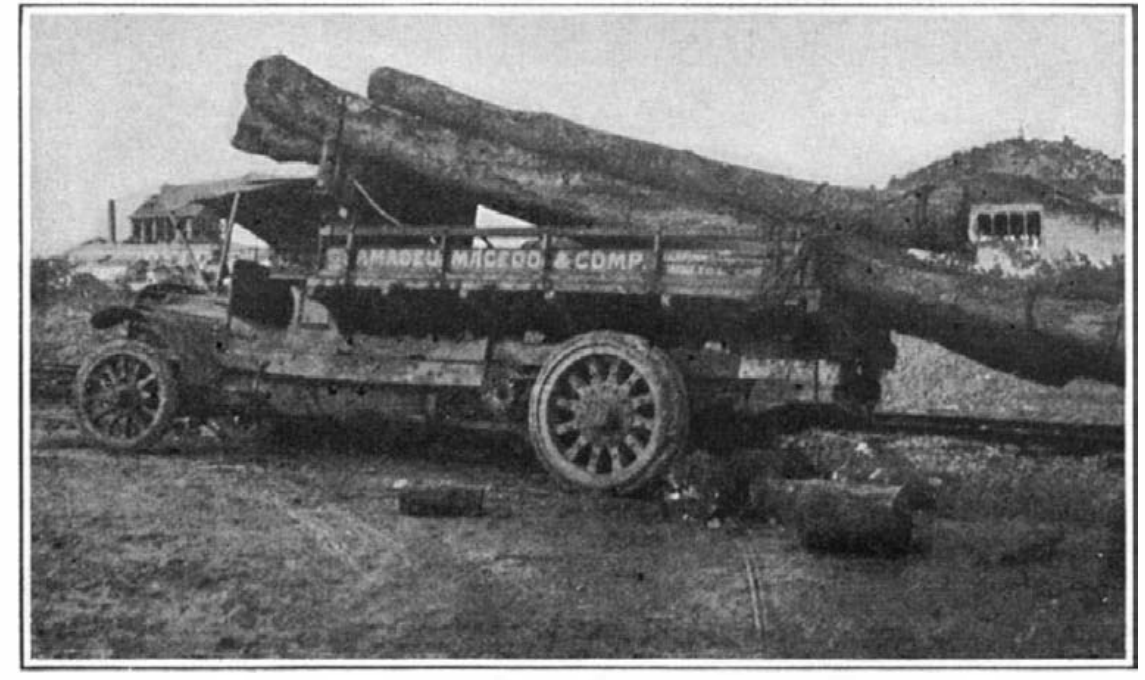

Handling rosewood from the yard to the pier at Rio de Janeiro
The total number of feet given liere represents approximately 3000 tons of logs in the rough, which confirms the estimates already made that there are about 1000 tons of true rosewood and about 2000 tons of substitutes entered here annually for consumption.

Rosewood is expensive, which militates somewhat against its more extensive use here, less so in Europe. While the price of true rosewood was about $\$ 100$ per long ton during the war, it can be laid down now in New York for less than half that figure. But even this is an unusual price for wood when it is calculated in term. per 1000 board feet. It requires approximately five tons of logs in the rough to yield 1000 board feet measured by a standard $\log$ rule, but this does not take into

Rosewood $\operatorname{logs}$, cut in half by the pit-saw in the foreground this country for all purposes is shown in the following table compiled by the United States Forest Service:
Total

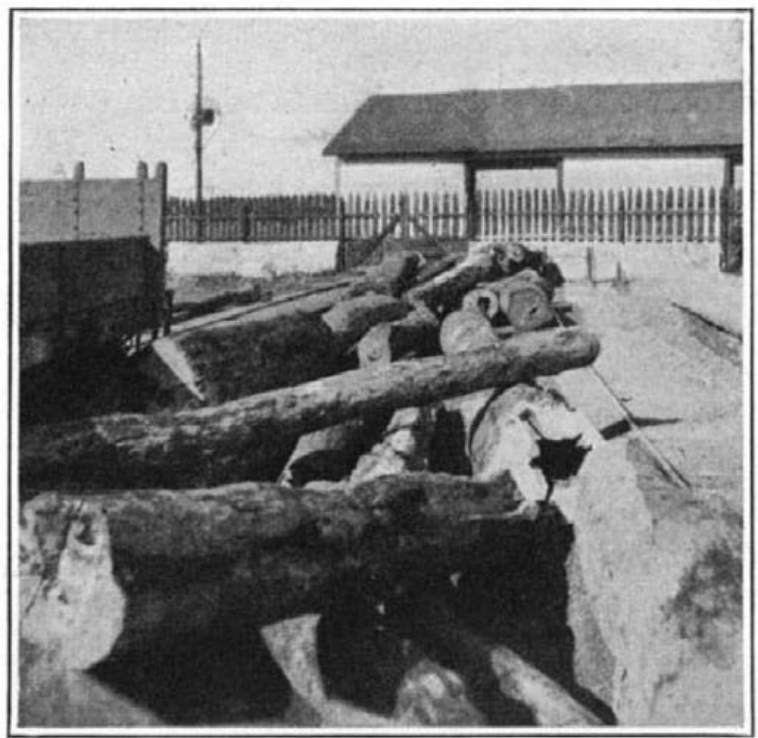

Rosewood logs, showing the common heart defect

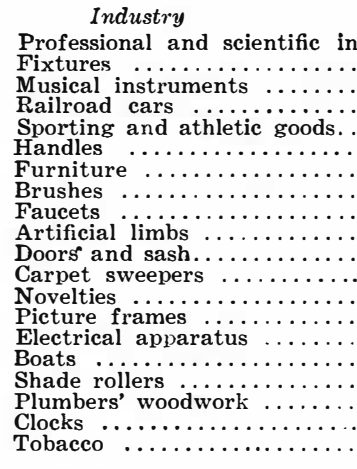
consideration the great amount of waste due to defects At $\$ 50$ per long ton figured on the basis of board feet it is $\$ 250$, but less than 200 board feet of this represents clear stock.

Quoting the Hardwood Record for October 25th, 1918: "The average price paid during a whole year for rosewood by manufacturers in Pennsylvania was $\$ 462.89$ per 1000 board feet. The wood is nearly always bought in the $\log$, and if it is purchased by weight, the price is figured on the foot basis. The average price during a year in Illinois was $\$ 233$; in New York, $\$ 219.89$, and in Connecticut, $\$ 225.40 . "$

\section{Petroleum Wastes and Savings}

A $\mathrm{N}$ investigation of losses of crude oil through evapA oration in storage and in transportation, conducted during the year by the Bureau of Mines, disclosed losses of startling magnitude. It was found that in the few days in which crude oil is stored on the lease before being taken by the pipeline the aggregate loss per year from evaporation amounts to about $122,000,000$ gallons of gasoline in the Mid-Continent field alone. This has a value, at 22 cents per gallon, of $\$ 26,840,000$, and represents about 3 per cent of the total gasoline produced in the United States from all fields and all sources. The bureau found that a large per cent of this loss could be prevented by the use of efficient equipment.

The Bureau of Mines has pointed out the considerable losses which have resulted from the failure of many refineries to recover gasoline from uncondensed still vapors. The significance of this investigation is shown by the fact that one refinery in the Mid-Continent field is now recovering from still vapors approximately 400 barrels of gasoline daily that before the installation of this equipment was either lost or burned as fuel under the boilers and stills. The value of fractionating towers at petroleum refineries, by means of which some companies have increased the yield of gasoline from crude oil by as much as 5 per cent or $162 / 3$ per cent of the total gasoline yield, has been demonstrated.

Large quantities of gas are now being wasted in the Osage Nation in Oklahoma because of low-pressure conditions, and the Bureau of Mines is investigating the feasibility of utilizing this waste gas by the use of lowpressure burners for oil-field boilers. The demand of the export marliet for "sweet" gasoline led to the development of a process for treating gasoline to remove the objection able sulfur compounds, by which treatment some grades of American gasoline heretofore objectionable were made suitable for export.

Under the arrangement by which supervision of the drilling and production of oil and gas on the public lands is vested in the Bureau of Mines, the bureau has supervision of about 100 producing oil properties which are producing at the rate of about $12,000,000$ barrels of oil per annum. A special process, devised at the San Francisco station of the bureau, for cracking heavy oils and tars promises the recovery of large yields of gasoline and other lighter products hitherto regarded as unrecoverable. Investigations made by the bureau in Colorado and Utah indicate that the oil-shale deposits of the Rocky Mountain States contain a potential fue supply of almost unequaled importance. 